\title{
LIETUVOS DIDELIO MEISTRIŠKUMO BAIDARININKŲ RENGIMO KETURMEČIU OLIMPINIU CIKLU YPATUMAI
}

\author{
Egidijus Balčiūnas \\ Vilniaus pedagoginis universitetas, Vilnius, Lietuva
}

Egidijus Balčiūnas. Sporto magistras. Vilniaus pedagoginio universiteto Sporto ir metodikos katedros socialinių mokslų srities edukologijos krypties fizinio lavinimo ir sporto šakos I kurso doktorantas. Mokslinių tyrimų kryptys: Lietuvos didelio meistriškumo baidarininkų rengimo keturmečiu olimpiniu ciklu analizè; baidarininkų fizinio išsivystymo, funkcinio pajègumo ir specialiojo darbingumo tyrimai.

\section{SANTRAUKA}

Didelio meistriškumo sportininku ugdymas — sudetingas edukacinis vyksmas, kurio tyrimai plačiai atliekami daugelio pasaulio šaliu mokslininku (Верхошанский, 1988; Čерulènas, 2001; Karoblis ir kt., 2002; Платонов, 2004; Issurin, 2008). Lietuvos baidarininku rengimas yra nemažai tyrinètas (Rudzinskas ir kt., 2001; Alekrinskis ir kt., 2003; Skernevičius ir kt., 2003). Rengimo technologija pakito pasikeitus varžybu nuotolio ilgiui ir jo iveikimo greičiams. Atskiri nuotoliai iš baidarininku reikalauja specialaus parengtumo (Issurin, 2008). Ypač sudètinga rengtis 500 m nuotolio varžyboms, kuriu metu baidarininko organizme vyksta daugybè biocheminiu procesu (Gailiūnienè, Milašius, 2001; Balčiūnas, Skernevičius, 2007).

Tyrimo objektas — Lietuvos didelio meistriškumo baidarininku rengimasis keturmečiu olimpiniu ciklu, ju parengtumo kaita. Tyrimo tikslas - išanalizuoti Lietuvos didelio meistriškumo baidarininku rengimo teorinę medžiaga, ištirti Lietuvos didelio meistriškumo baidarininku rengima per keturmeti olimpini cikla.

Ištirti 2 pajégiausi Lietuvos baidarininkai, kurie rengèsi Europos, pasaulio čempionatams ir olimpinėms žaidynėms. Buvo ištirta fiziniu ir funkciniu galiu kaita per keturmeti olimpini cikla. Išnagrinèti treniruočiu planavimo ir apskaitos dokumentai, sportininku dienoraščiai. Fizinès ir funkcinès galios tirtos atskiru metiniu ciklu parengiamojo laikotarpio pradžioje, parengiamojo laikotarpio specialiojo rengimo etapu, varžybu laikotarpio parengiamuju varžybu etapu, prieš pagrindines varžybas ir ju metu.

Išnagrinèjus olimpinio ciklo metinius fizinius krūvius matyti, kad sportininkai per metus treniravosi pakankamai daug dienu ir atliko tinkamq pratybu krūvį. Jos sukèle reikiamus organizmo pokyčius rengiantis ǰveikti $500 \mathrm{~m}$ nuotoli, tačiau nuvykimo į olimpines žaidynes laiko nepavyko gerai pasirinkti. Startuoti teko tada, kai organizme vyko dideli funkciniu sistemu pokyčiai, smarkai sumažejo fizinis ir funkcinis pajégumas. Išanalizavus keturmečio olimpinio ciklo varžybu laikotarpio pagrindiniu varžybu mezocikla matyti, kad jis sudarytas ir pagristas sporto mokslo samprata. Baidarininku pratybu mikrociklu struktūra aiški, išryškintos dvi glikolitinės treniruotés mikrociklo metu, pratybos tikslingos, glaustos ir labai specializuotos rengiantis jiveikti 500 m nuotoli, tačiau baigiamuoju pasirengimo mikrociklu prieš pagrindinius startus padidinus irklavimo tempa nespèta tam prisitaikyti. Per keturmeti olimpini cikla fizinio išsivystymo rodikliai, raumenu masè kito nedaug, specialaus $500 \mathrm{~m}$ simuliacinio testo rodikliai vis didejo, specialusis anaerobinis alaktatinis galingumas pamažu didejjo. Nuvykimas $i$ olimpines žaidynes likus iki varžybu 6 d. buvo pražùtingas, startai sutapo su fizinio darbingumo sumažejimo, aklimatizacijos faze. Padidintas irklavimo tempas nebuvo racionalus. Olimpinèse žaidynèse užimta 11 vieta netenkino nei sportininku, nei ju rengèju.

Raktažodžiai: fizinis išsivystymas, fizinis parengtumas, funkcinis pajėgumas, fiziniai krūviai, metinis ciklas, mezociklas, mikrociklas.

\section{IVADAS}

K eturmetis olimpinis ciklas — sportininku rengimo laikotarpis tarp dviejų olimpinių žaidynių. Tokia daugiamete perspektyvinio sportinio rengimo struktūra leidžia tinkamai planuoti rengimo eigą, derinti fizinius krūvius, garantuoja sportininkų meistriškumo didejjimą. Kiekvieno metinio ciklo struktūra kartojasi, tačiau metu rengimo turinys kinta ir turi atitikti vis didesnius organizmo adaptacijos pokyčio reikalavimus (Матвеев, 1999).
Baidarių irklavimo sporto šakos varžybinè veikla sietina su anaerobiniais ir aerobiniais procesais (Byrnes, Kearney, 1997; Шуматов, Шантарович, 2008) bei specifiniais morfologiniais organizmo adaptacijos reiškiniais (Clarkson et al., 1982; Skernevičius ir kt., 2007 ).

Lietuvos baidarininkų rengimas yra nemažai tyrinètas (Alekrinskis ir kt., 2003, 2005; Skernevičius ir kt., 2003; Rudzinskas ir kt., 2004). Baidarininkų rengimo technologija ypač pakito pasikeitus 
varžybų nuotolio ilgiui ir jo ịveikimo greičiams. Atskiri nuotoliai iš baidarininkų reikalauja specialaus parengtumo (Issurin, 2008). Ypač sudètinga rengtis 500 m nuotolio varžyboms, kurių metu baidarininko organizme vyksta daugybè biocheminių procesų (Stasiulis ir kt., 1998; Gailiūniené, Milašius, 2001; Balčiūnas, Skernevičius, 2007).

Baidarininku 500 m nuotolio varžybos ittrauktos į olimpinių žaidynių programą, todèl pasirengti joms skiriamas keturmetis olimpinis ciklas. Visgi nėra pakankamai tyrimų, kurių metu būtų moksliškai ištirtas baidarininkų rengimas $500 \mathrm{~m}$ nuotolio varžyboms per keturmeti olimpini ciklą. Todèl aktualu moksliškai išnagrinèti didelio meistriškumo baidarininkų rengimą Lietuvos klimatinèmis, ekonominèmis ir socialinèmis sąlygomis.

Kintant socialinėms, ekonominėms sąlygoms, plètojant sportą, didejjant konkurencijai iškyla problema, kaip tobulinti Lietuvos didelio meistriškumo baidarininkų rengima, kad jų meistriškumas pasiektų tarptautini lygị, leistų iškovoti medalius svarbiausiose varžybose. Šios problemos sprendimui tikslinga pasitelkti edukologijos ir sporto mokslo tyrimų metodologiją.

Tyrimo objektas - Lietuvos didelio meistriškumo baidarininkų rengimasis keturmečiu olimpiniu ciklu, ju parengtumo kaita.

Tyrimo tikslas - ištirti Lietuvos didelio meistriškumo baidarininkų rengimąsi olimpinèms žaidynėms keturmečiu olimpiniu ciklu.

\section{Uždaviniai:}

1. Išnagrinèti olimpinio ciklo metinius fizinius krūvius, jų veiksmingumą.

2. Išanalizuoti konkrečius mezo- ir mikro- ciklus, atskiras pratybas.

3. Ištirti sportininkų parengtumo raidą olimpiniu keturmečiu ciklu.

\section{TYRIMO ORGANIZAVIMAS IR METODIKA}

2005-2008 metais ištirti 2 pajègiausi Lietuvos baidarininkai, besirengiantys Europos, pasaulio čempionatams ir olimpinèms žaidynèms pagal programą „Pekinas-2008“. Buvo ištirta fizinių ir funkcinių galių kaita keturmečiu olimpiniu ciklu. Išnagrinèti treniruočių planavimo ir apskaitos dokumentai, sportininku dienoraščiai. Fizinès ir funkcinès galios tirtos atskiru metinių ciklu parengiamojo laikotarpio pradžioje, parengiamojo laikotarpio specialiojo rengimo etapu, varžybų laikotarpio parengiamujų varžybų etapu, prieš pagrindines varžybas ir jų metu.

Buvo matuojami pagrindiniai fizinio išsivystymo rodikliai: ūgis, kūno masè, plaštakų jèga, gyvybinis plaučių tūris (GPT), riebalų, raumenu masė. Taip pat tirta: vienkartinis raumenu susitraukimo galingumas (VRSG), anaerobinis alaktatinis raumenų galingumas (AARG), judesių dažnis per $10 \mathrm{~s}$, psichomotorinès reakcijos laikas (PRL), Rufjè indeksas.

Specialusis parengtumas vertinamas pagal rezultatus, pasiektus įveikiant $500 \mathrm{~m}$ simuliacini nuotoli „Dansprint“ ergometru fiksuojant darbo laika, galinguma, yrių tempa, pulso dažni, kraujospūdžio reakciją i fizini krūvị ir atsigavimo eiga per 3 min. Baigus atlikti krūvi, po $3-5$ min buvo imamas kraujas iš piršto, nustatoma laktato $(\mathrm{La})$, hemoglobino koncentracija (Hb), kraujo plazmos ir jo ląstelinių elementų kiekio santykis hematokritu (Ht).

Ergometru buvo nustatomas anaerobinis alaktatinis specialusis galingumas dirbant $10 \mathrm{~s}$ maksimaliomis pastangomis. Taip pat nustatytas galingumas ties anaerobinio slenksčio riba (W), pulso dažnis (PD), laktato koncentracija kraujyje (La). Taikyta tyrimų metodika, aprašyta J. Skernevičiaus ir kt. (2004).

\section{REZULTATAI}

Nagrinèjant tirtų baidarininkų fizinį krūvị keturmečiu olimpiniu ciklu rengiantis Pekino olimpinėms žaidynèms (OŽ) matyti, kad per metus buvo treniruotasi vidutiniškai 285 dienas, pratybu skaičius svyravo nuo 395 iki 435, daugiausia kilometrų nuirkluota olimpiniais metais - $3800 \mathrm{~km}$ (1 lent.).

Baidarininkų metinis rengimosi ciklas suskirstytas laikotarpiais: pereinamaji, parengiamaji, varžybų. Parengiamuoju laikotarpiu buvo išskirti: bazinio rengimo, specialusis rengimo, o varžybiniu laikotarpiu - parengiamujų varžybų, pagrindinių varžybų etapai. Iš ketvirtų olimpinio

\begin{tabular}{|c|c|c|c|c|}
\hline Atliktas darbas & Pirmi metai & Antri metai & Treti metai & Ketvirti metai \\
\hline Pratybų dienų skaičius & 270 & 290 & 280 & 300 \\
\hline Pratybų skaičius & 395 & 435 & 403 & 460 \\
\hline Laikas, skirtas pratyboms, h & 1050 & 1000 & 1030 & 1150 \\
\hline Nuirkluota km & 3400 & 3600 & 3500 & 3800 \\
\hline
\end{tabular}

1 lentelè. Keturmečio olimpinio ciklo fizinių krūvių suvestinè 
2 lentelè. Baidarininkų darbo apskaita keturmečio olimpinio ciklo ketvirtais metais

\begin{tabular}{|c|c|c|c|c|c|c|c|c|c|c|c|c|c|}
\hline \multirow{3}{*}{$\begin{array}{l}\text { Etapai } \\
\text { Mènesiai (mezociklai) }\end{array}$} & \multicolumn{2}{|c|}{ Pereinamasis } & \multicolumn{6}{|c|}{ Parengiamasis } & \multicolumn{4}{|c|}{ Varžybinis } & \multirow{3}{*}{ Iš viso } \\
\hline & & & \multicolumn{3}{|c|}{ Bazinis rengimas } & \multicolumn{3}{|c|}{$\begin{array}{c}\text { Specialusis } \\
\text { rengimas }\end{array}$} & \multicolumn{3}{|c|}{ Parengiamųjų varžybų } & \multirow{2}{*}{\begin{tabular}{|c|}
$\begin{array}{c}\text { Pagr. } \\
\text { varžybų }\end{array}$ \\
8
\end{tabular}} & \\
\hline & 9 & 10 & 11 & 12 & 1 & 2 & 3 & 4 & 5 & 6 & 7 & & \\
\hline Pratybų dienų sk. & 24 & 21 & 26 & 26 & 26 & 24 & 26 & 25 & 25 & 35 & 26 & 26 & 300 \\
\hline Pratybų sk. & 24 & 21 & 45 & 42 & 43 & 41 & 44 & 40 & 42 & 40 & 40 & 40 & 460 \\
\hline Bendras valandų sk. & 80 & 50 & 90 & 100 & 110 & 100 & 110 & 100 & 100 & 110 & 100 & 100 & 1150 \\
\hline SFP & 70 & 25 & 45 & 50 & 70 & 40 & 40 & 20 & 15 & 31 & 10 & 10 & 426 \\
\hline SR & 10 & 25 & 45 & 50 & 40 & 60 & 70 & 80 & 85 & 79 & 90 & 90 & 724 \\
\hline Varžybų sk. / startų sk. & 0 & 0 & 0 & $1 * 1$ & 0 & 0 & 0 & 0 & 2,6 & $2 * 10$ & $1 * 2$ & $1 * 2$ & $7 * 21$ \\
\hline Nuirkluota km & 100 & 60 & 300 & 320 & 250 & 450 & 490 & 480 & 320 & 350 & 380 & 300 & 3800 \\
\hline 1 zona: iki 150 p.d. La 4 m.mol & 70 & 20 & 150 & 180 & 100 & 200 & 230 & 185 & 100 & 160 & 215 & 150 & 1760 \\
\hline 2 zona: $151-186$ p.d. La $5-10$ m.mol & 25 & 40 & 150 & 120 & 100 & 170 & 200 & 220 & 170 & 130 & 110 & 90 & 1525 \\
\hline 3 zona: 186 - p.d. La $11-18$ m.mol & 5 & & 0 & 20 & 50 & 75 & 57 & 70 & 42 & 50 & 48 & 45 & 462 \\
\hline 4 zona: maks. intensyvumas & 0 & 0 & 0 & 0 & 0 & 5 & 3 & 5 & 8 & 10 & 7 & 15 & 53 \\
\hline
\end{tabular}

Pastaba. SFR — specialusis fizinis rengimasis; SR — specialusis rengimasis.

ciklo metų baidarininkų rengimo apskaitos matyti, kad sportininkai, besirengiantys svarbiausioms sezono varžyboms pereinamuoju laikotarpiu, turejjo 45 pratybas, kurių metu buvo akcentuojamas sportininkų organizmo funkcinių ir fizinių galiu palaikymas.

Parengiamasis laikotarpis prasidejjo lapkričio mėnesio pradžioje bazinio rengimo etapu. Jis truko tris mènesius, kiekvieno mezociklo metu vidutiniškai treniruotasi po 26 dienas ir atlikta po 43 i̇vairaus intensyvumo pratybas, kurios truko vidutiniškai $100 \mathrm{~h}$.

Specialiojo rengimo etapu per vieną mezociklą dirbta nuo 100 iki 110 h, iš jų 40 h skirta specialiajam fiziniam rengimui, $70 \mathrm{~h}$ - specialiajam rengimui. Abiejų mikrociklų metu nuirkluota 470 ir $490 \mathrm{~km}$, iš ju pirmoje intensyvumo zonoje ivveikta $230 \mathrm{~km}$, antroje $-200 \mathrm{~km}$, trečioje $-57 \mathrm{~km}$, ketvirtoje $-3 \mathrm{~km}$ (2 lent.).

Varžybų laikotarpis prasidėjo gegužès mėnesi ir tęsėsi keturis mezociklus. Parengiamujų varžybų etapu dalyvauta penkiose varžybose, 18 kartu startuota pagrindinių varžybų etapu ir 2 kartus startuota pagrindinèse varžybose.

Per varžybų laikotarpio pagrindinių varžybų etapą (mezociklą) atlikto krūvio rodikliai, pateikti 1 paveiksle, rodo aerobinio darbo, mišraus aerobinio glikolitinio ir kreatinfosfatinio darbo laiką procentais per mezociklą. Per pirmą mikrociklą trejos pratybos vyko vyraujant mišriam energijos gamybos būdui, per vienerias dominavo glikolitinis, per trejas - kretinfosfatinis energijos gamybos būdas. Antro mikrociklo metu vyko dvejos glikolitinio energijos gamybos būdo pratybos, vienerios aerobinio pobūdžio ir nedideli procentą užima kretinfosfatinio galingumo ugdymo pratybos. Trečio ir ketvirto mikrociklo metu vyrauja mišrios energijos gamybos ir glikolitines reakcijas skatinančios pratybos.

Didelio fizinio krūvio mikrociklas išdėstytas pagal savaitės dienas nuo pirmadienio iki sekmadienio. Akcentuojamosios didelio krūvio ir intensyvumo pratybos buvo atliekamos antradieni, ketvirtadieni ir šeštadieni. Tose pratybose laktato koncentracija kraujyje siekdavo 12-16 mmol / l, pulso dažnis - iki 180 tv. / min. Anaerobinio alaktatinio raumenu galingumo ugdymo ir greičio didinimo pratybos vyko pirmadieni vakare irkluojant ir antradienį vakare treniruojantis saleje. Aerobinio pobūdžio pratybos pirmadienį buvo vykdomos ryte, jų trukmè - 1 h 20 min. PD siekè vidutiniškai 139 ir 174 tv. / min, daugiausia ju metu nuirkluota 16 kilometru.

Kontrolinės pratybos, kurių metu buvo įveikiamas varžybų nuotolis, atliekamos šeštadieni. Jų metu du kartus irkluota 500 m vienviete baidare ir du kartus dviviete. Poilsis tarp nuotolio tarpu iveikimo - 15-20 minučių. Vienviete baidare pasiektas rezultatas: pirmame nuotolio tarpe 1 min 46 s, PD — vidutiniškai 178 tv. / min; antrame -1 min $42 \mathrm{~s}$, maksimalus PD $-181 \mathrm{tv}$. / min. $500 \mathrm{~m}$ nuotolio įveikimo laikas irkluojant dviviete baidare -1 min $36 \mathrm{~s}$. Maksimalusis momentinis nuotolio įveikimo greitis - 6,41 m / s, vidutinis $5,29 \mathrm{~m} / \mathrm{s}$. Sportininko A. D. maksimalusis PD 177 tv. / min, E. B. - 178 tv. / min.

Sportininkų A. D. ir E. B. pulso dažnio kreivès iveikiant visus tris nuotolio tarpus išdèstytos 2 pa- 


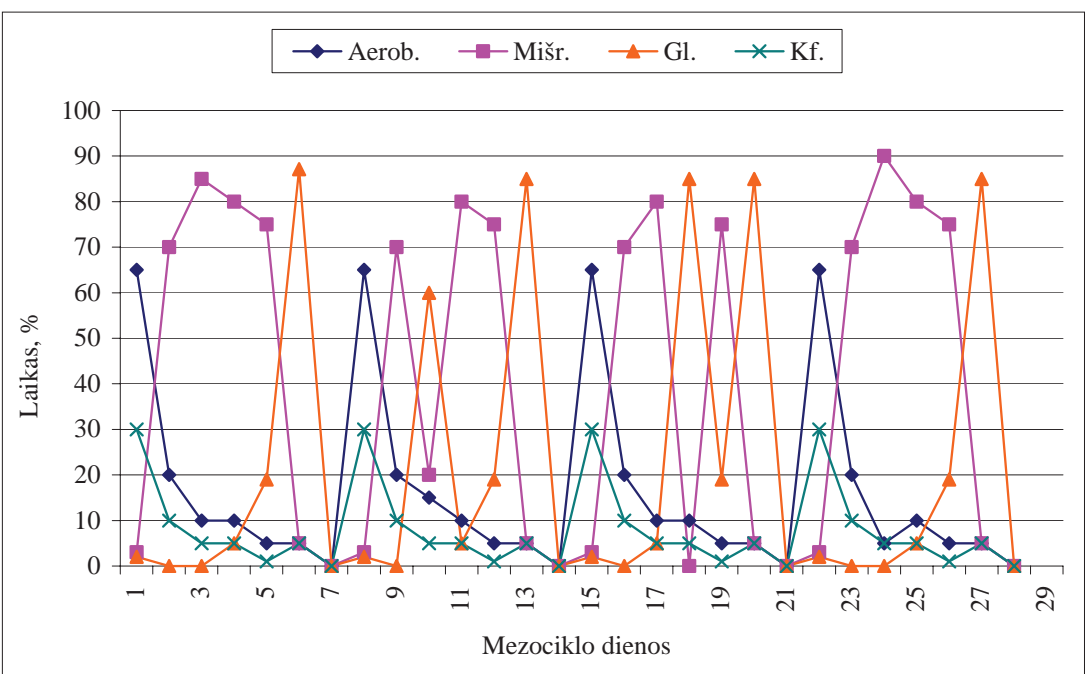

1 pav. Laiko, skiriamo darbui įvairiose energijos gamybos zonose varžybiniu laikotarpiu, pagrindinių varžybų mezociklų diagrama

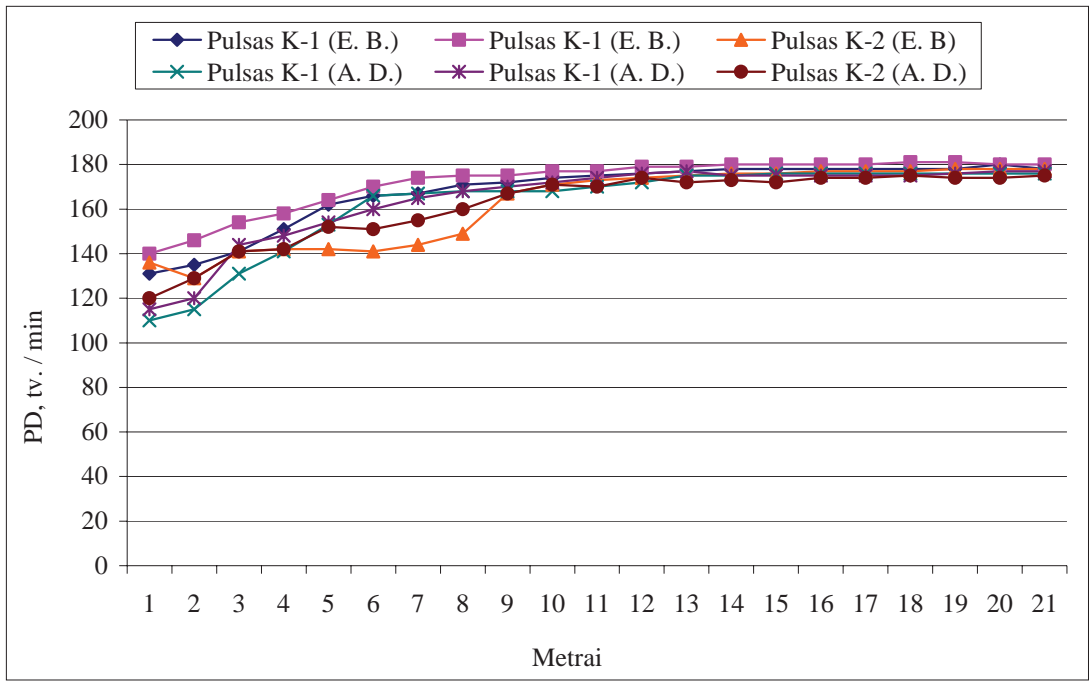

2 pav. Pulso dažnio kreivė priešvaržybiniu mikrociklu, atliekant kartotinị $3 \times 500$ m krūvị

veiksle. Išanalizavus PD kreives galima teigti, kad sportininkai, įveikdami $500 \mathrm{~m}$ nuotoli, pasiekia maksimaluji pulso dažni - 181 tv. / min. Sportininkams irkluojant dviviete baidare nustatytas pulso dažnio skirtumas - jis A. D. mažesnis.

Per visą keturmetį olimpini ciklą sportininkai startavo i̇vairaus rango kontrolinėse, komercinèse, nacionalinėse ir tarptautinėse varžybose. Bet didžiausias dėmesys pasirengimo metu buvo skirtas olimpinėms žaidynėms. 3 lentelèje matyti, kad kiekvienais metais sportininkai vidutiniškai startuodavo 7 varžybose, iš jų 3 buvo Lietuvoje ir 4 užsienyje. Startų skaičius per metus svyruoja nuo 39 iki 20 olimpiniais metais. Dalyvauta įvairiu valčių klasių (K-1, K-2, K-4) varžybose. Daugiausia (apie 90\%) startuota dvivietėmis baidarėmis. Per olimpiniu metu varžybu mezociklą dalyvauta 6 varžybose, startuota 20 kartu, iš jų ir Pekino olimpinėse žaidynėse (3 lent.).

Per keturmeti olimpini ciklą iškovota nemažai puikių apdovanojimų. Pasaulio taurès etapuose iškovota 16 ịvairių spalvų medalių. Europos čem- pionatuose laimèti du sidabro ir vienas bronzos medaliai. Pasaulio čempionate — du apdovanojimai ir olimpinėse žaidynėse užimta 11 vieta.

Nagrinėjant tirtų baidarininkų fizinio išsivystymo duomenis matyti, kad per ši olimpini ciklą sportininkų kūno masė kito nedaug (4 lent.). Sportininkų plaštakų jègos rodikliai nesikeičia jau daugeli metų. A. D. dešinès rankos siekia $55 \mathrm{~kg}$, kairès - $65 \mathrm{~kg}$, E. B. dešinès rankos - $65 \mathrm{~kg}$, kairès - $55 \mathrm{~kg}$. Gyvybinis plaučių tūris (GPT) abiejų sportininku sieke 6 litrus, tai optimalus baidarininku rodiklis. Abiejų baidarininkų raumenų masé visą keturmeti olimpini ciklą turèjo tendenciją didèti $3-4 \mathrm{~kg}$. E. B. riebalų masẻ buvo maža ir svyravo nuo 5,4 iki 5,7 kg, o A. D. - nuo 6,5 iki 8,7 kg.

Tirtu baidarininkų vienkartinio raumenų susitraukimo galingumo rodikliai skiriasi, bet per visą tirtą laikotarpi didelių pokyčių nenustatyta. Sportininku anaerobinio alaktatinio raumenu galingumo rodikliai skyrèsi mažai. Tiriamuoju laikotarpiu E. B. jie siekè 1493-1570 W, A. D. - 
3 lentelè. Baidarininkų A. D ir E. B. varžybų ir startų suvestinė keturmečiu olimpiniu ciklu

\begin{tabular}{|l|l|l|l|l|l|l|l|}
\hline \multicolumn{1}{|c|}{ Varžybos } & Tarptautinès & Liet. čemp. \\
komercinès & Liet. taure & $\begin{array}{c}\text { Pasaulio } \\
\text { tauré }\end{array}$ & $\begin{array}{c}\text { Europos } \\
\text { čemp. }\end{array}$ & $\begin{array}{c}\text { Pasaulio } \\
\text { čemp. }\end{array}$ & $\begin{array}{c}\text { Olimpinės } \\
\text { žaidynès }\end{array}$ & Iš viso \\
\hline 2005 & $2 / 3$ & $1 / 2$ & $3 / 21$ & $1 / 7$ & $1 / 6$ & & $8 / 39$ \\
\hline 2006 & $3 / 8$ & $1 / 4$ & $2 / 10$ & $1 / 5$ & $1 / 6$ & & $8 / 33$ \\
\hline 2007 & $1 / 2$ & $1 / 3$ & $3 / 19$ & $1 / 5$ & $1 / 6$ & & $7 / 35$ \\
\hline 2008 & $1 / 2$ & $1 / 1$ & $2 / 10$ & $1 / 5$ & & $1 / 2$ & $6 / 20$ \\
\hline
\end{tabular}

4 lentelè Baidarininkų fizinio išsivystymo, raumenų ir riebalų masès santykio rodiklių kaita keturmečiu olimpiniu ciklu

Pastaba. KMI - kūno masès indeksas; RRMI — raumenų riebalų masès indeksas.

\begin{tabular}{|c|c|c|c|c|c|c|c|c|c|c|}
\hline \multirow{2}{*}{$\begin{array}{l}\text { Baidarinin- } \\
\text { kų inicialai }\end{array}$} & \multirow{2}{*}{ Data } & \multirow{2}{*}{$\begin{array}{l}\text { Ūgis, } \\
\text { cm }\end{array}$} & \multirow{2}{*}{$\begin{array}{c}\text { Kūno } \\
\text { masé, } \\
\text { kg }\end{array}$} & \multirow{2}{*}{$\begin{array}{l}\text { KMI, } \\
\mathrm{kg} / \mathrm{m}^{2}\end{array}$} & \multicolumn{2}{|c|}{ Jèga, kg } & \multirow{2}{*}{ GPT, I } & \multirow{2}{*}{$\begin{array}{c}\text { Raum., } \\
\text { kg }\end{array}$} & \multirow{2}{*}{$\begin{array}{c}\text { Rieb., } \\
\text { kg }\end{array}$} & \multirow{2}{*}{ RRMI } \\
\hline & & & & & D & $\mathbf{K}$ & & & & \\
\hline E. B. & 20050517 & 189,0 & 86,5 & 24,2 & 54 & 48 & 6,1 & 50,1 & 5,7 & 8,72 \\
\hline A. D. & 20050517 & 191,0 & 87,0 & 24,1 & 50 & 56 & 5,9 & 52 & 6,5 & 7,97 \\
\hline E. B. & 20060724 & 189,0 & 86,0 & 24,1 & 53 & 48 & 6,5 & 50,0 & 5,6 & 8,62 \\
\hline A. D. & 20060724 & 191,0 & 86,0 & 23,4 & 48 & 58 & 6,3 & 51 & 7,2 & 7,13 \\
\hline E. B. & 20070710 & 189,0 & 88,0 & 24,4 & 65 & 56 & 6,0 & 50,7 & 5,4 & 9,41 \\
\hline A. D. & 20070710 & 191,0 & 92,0 & 25,5 & 66 & 60 & 5,8 & 56,8 & 8,5 & 6,68 \\
\hline E. B. & 20080612 & 189,0 & 88,4 & 25,5 & 65 & 55 & 6,3 & 54 & 5,5 & 9,69 \\
\hline A. D. & 20080612 & 191,0 & 90,5 & 25,1 & 55 & 65 & 6,0 & 55,4 & 8,7 & 6,35 \\
\hline
\end{tabular}

5 lentelè. Baidarininku vienkartinio raumenu susitraukimo galingumo (VRSG), anaerobinio alaktatinio raumenu galingumo (AARG), psichomotorinès reakcijos laiko (PRL), judesių dažnio (j. d.) rodiklių kaita keturmečiu olimpiniu ciklu

\begin{tabular}{|c|c|c|c|c|c|c|c|c|c|}
\hline \multirow{2}{*}{$\begin{array}{c}\text { Baidarininkų } \\
\text { inicialai }\end{array}$} & \multirow{2}{*}{ Data } & \multirow{2}{*}{$\begin{array}{l}\text { Aukštis, } \\
\text { cm }\end{array}$} & \multirow{2}{*}{$\begin{array}{c}\text { Laikas, } \\
\text { mls }\end{array}$} & \multicolumn{2}{|c|}{ VRSG } & \multicolumn{2}{|c|}{ AARG } & \multirow{2}{*}{ PRL, ms } & \multirow{2}{*}{$\begin{array}{c}\text { J. d., } \\
\text { k. / } 10 \text { s }\end{array}$} \\
\hline & & & & W & $\mathrm{W} / \mathrm{kg}$ & $\mathbf{W}$ & $\mathrm{W} / \mathrm{kg}$ & & \\
\hline E. B. & 20050517 & 70 & 256 & 2315 & 26,76 & 1569 & 18,14 & 149 & 81 \\
\hline A. D. & 20050517 & 62 & 166 & 3255 & 36,57 & 1693 & 19,02 & 132 & 75 \\
\hline E. B. & 20060620 & 58 & 247 & 2004 & 23,04 & 1493 & 17,16 & 157 & 73 \\
\hline A. D. & 20060620 & 55 & 178 & 2691 & 29,90 & 1659 & 18,43 & 162 & 87 \\
\hline E. B. & 20070710 & 51 & 196 & 2243 & 25,49 & 1570 & 17,84 & 148 & 77 \\
\hline A. D. & 20070710 & 56 & 188 & 2711 & 29,22 & 1674 & 18,03 & 139 & 96 \\
\hline E. B. & 20080612 & 43 & 239 & 1544 & 17,65 & 1535 & 17,55 & 177 & 70 \\
\hline A. D. & 20080612 & 49 & 194 & 2282 & 24,80 & 1624 & 17,65 & 134 & 82 \\
\hline
\end{tabular}

1624-1693 W. Baidarininko E. B. judesių dažnis svyravo nuo 70 iki 81 k. / 10 s, baidarininko A. D. - nuo 75 iki 96 k. / 10 s. E. B. PRL kito nedaug - 148-177 ms, A. D. - 132-162 ms (5 lent.).

Nagrinejjant baidarininku E. B ir A. D. kraujotakos ir kvėpavimo sistemų funkciniu galių kaita per visą keturmeti olimpini ciklą matyti, kad Rufjè indeksas tiriamuoju laikotarpiu kito nedaug. Iš pulso dažnio, užfiksuoto ramybès metu prieš fizini krūvi, galima spręsti apie tos dienos, tos valandos sportininko fizinę būklę. Tirtų baidarininkų reakcijos ị standartini fizinį krūvị (30 atsitūpimu per 45 s) rodikliai kito labai mažai ir siekè 112-117 tv. / min. Sistolinis ir diastolinis kraujospūdžio rodiklių svyravimas neperžengè fiziologinès normos ribos.

Specialiojo darbingumo testo, atlikto „Dansprint“ ergometru, rezultatai parode (3 pav.), kad sportininkas E. B. 500 m nuotoli 2005 m. ivveikdavo per $109 \mathrm{~s}$ ir pasiekdavo vidutiniškai $330 \mathrm{~W}$ darbo galinguma. Testavus sportininką visus ketverius pasirengimo metus, matyti progresinè rodikliu kaita 500 m nuotoli irkluojant ergometru. Jie geriausi buvo olimpiniais metais ir siekè $102 \mathrm{~s}$, o išugdomas galingumas - $388 \mathrm{~W}$.

Specialusis anaerobinis alaktatinis galingumas 10 s darbo metu kasmet vis didejo (4 pav.). Abieju tirtų sportininkų maksimalusis darbo galingumas kiekvienais metais vis didejjo. A. D., irkluodamas $10 \mathrm{~s}$ maksimaliomis pastangomis, pirmais metais pasiekė $740 \mathrm{~W}$ galinguma, E. B. $-760 \mathrm{~W}$. Olimpiniais metais didžiausias $\mathrm{A}$. D. darbo galingumas siekè 860 W, E. B. - 850 W. 10 s trukmès darbo galingumo vidurkis taip pat kito. A. D. 2006 m. šis rodiklis pasiekè vidutiniškai $568 \mathrm{~W}, 2008$ m. jis išaugo iki 795 W. E. B. šis rodiklis išaugo nuo 570 iki700 W. 

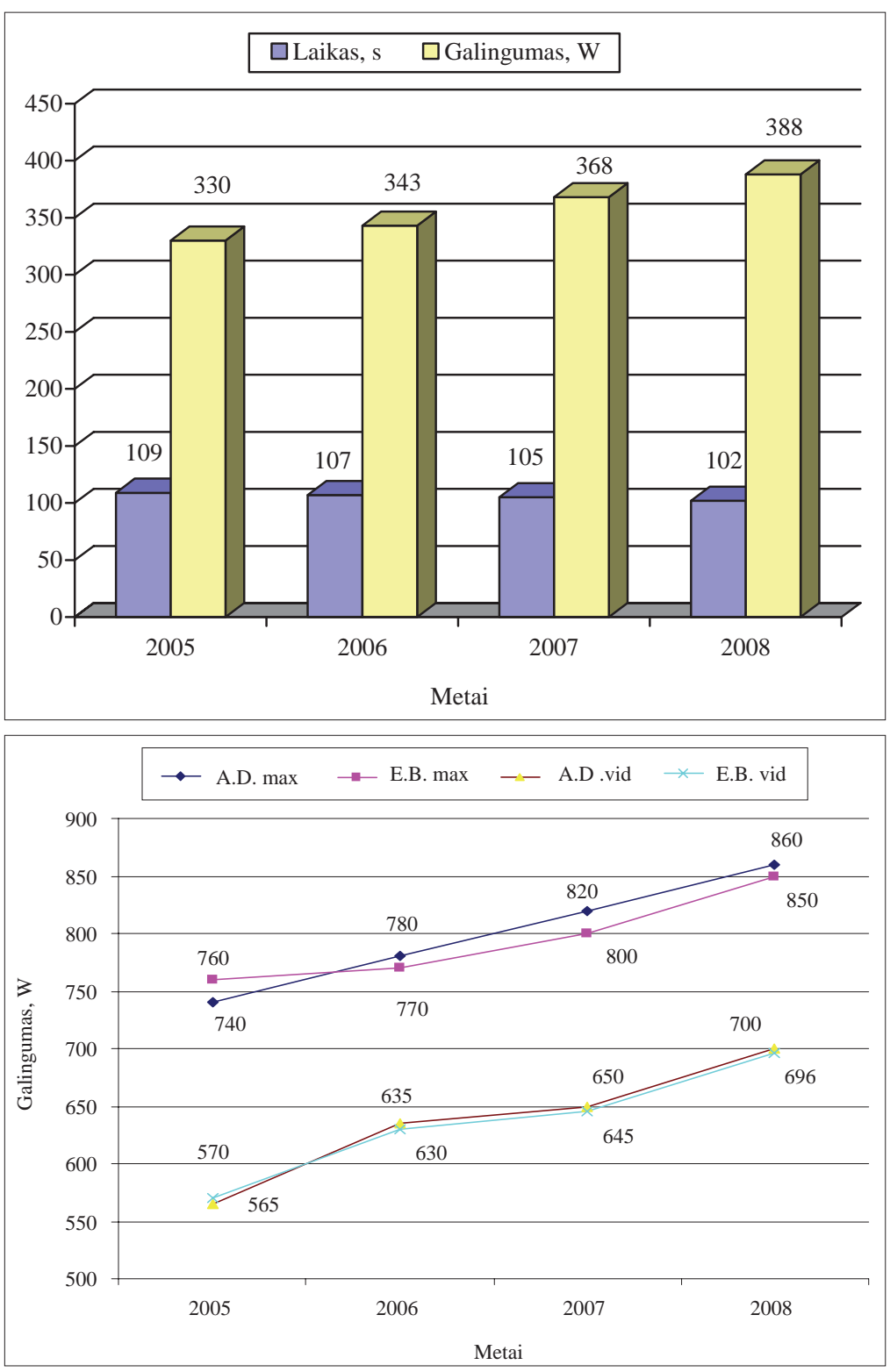

3 pav. E. B. $500 \mathrm{~m}$ simuliacinio testo ergometru laikas ir vidutinis galingumas
4 pav. $10 \mathrm{~s}$ maksimalaus ir vidutinio galingumo rodiklių kaita keturmečiu olimpiniu ciklu

\section{REZULTATUQ APTARIMAS}

Išanalizavus baidarininkų keturmeti olimpini ciklą matyti, kad sportininkai kiekvienais olimpinio ciklo metais nuirkluodavo vis daugiau kilometru. 2005 m. jie iqveike 3200 km, 2008 m. — 3800 km. Bet tai nèra daug, lyginant su V. Isurino (2008) pateiktais duomenimis. Jis nurodo $4200 \mathrm{~km}$ apimties irklavimo krūvị per metus. Sportininkų rengimosi programoje buvo numatyta 25 dienu mezociklo trukmė, kurios, kaip nurodo M. Rudzinskas ir kt. (2004), visiškai pakanka rengiantis pagrindiniams startams. Nagrinèjant A. D. ir E. B. varžybų laikotarpio didelio fizinio krūvio mezociklus, mikrociklus ir lyginant juos su kitų baidarininkų duomenimis (Skernevičiaus ir kt. 2004) matyti, kad tirti sportininkai mikrociklų metu atlieka ir dvejas glikolitinių reakcijų ugdymo pratybas.
Sportininku fizinio išsivystymo duomenys per keturmetị olimpinị ciklą kito mažai. Varžybų laikotarpiu, artėjant olimpinėms žaidynėms, labiau didejjo raumenų masé. Tirtų sportininkų vienkartinio raumenu susitraukimo galingumo ir aerobinio alaktatinio raumenų galingumo rodikliai gana nevienodi ir jų kaita skirtinga. Lyginant juos su ankstesnio laikotarpio tyrimais ir skirtingais pasirengimo etapais (Milašius ir kt., 1997; Stasiulis ir kt., 1998) matyti, kad A. D. šie rodikliai ypač dideli, E. B. per tirtą laikotarpi jie pamažu didejo.

Nagrinèjant baidarininkų kraujotakos ir kvèpavimo funkcijų kaitą varžybų laikotarpiu, didelių pakitimu neaptikta. Rufje indeksas kito nedaug, atsigavimo rodikliai po standartinio fizinio krūvio taip pat mažai pasikeitè.

Tyrimai parodè, kad Lietuvos baidarininkai, besirengiantys lenktyniauti $500 \mathrm{~m}$ nuotolio var- 
žybose, pasiekė dideli specialujji anaerobini glikolitini galingumą. $500 \mathrm{~m}$ irklavimo ergometru rodikliai kiekvienais metais, artėjant olimpinėms žaidynėms, vis gerèjo, ir tai sietina su maksimalaus specialiojo galingumo didejjimu.

Per paskutinį mezociklą prieš olimpines žaidynes kontrolinèse 500 m nuotolio varžybose buvo pasiektas didelis greitis. Tačiau nuvykus i Pekiną iki varžybų likus 6 dienoms labai pablogejjo sportininkų savijauta, aklimatizacija buvo sunki, savijauta varžybų metu prasta, olimpiniame kaimelyje tyrèjų nebuvo, kiekybinių duomenų apie irkluotoju fizinę ir funkcinę būklę neturèta, informacija gauta apklausos metodu.

Sumažèjus raumenų galingumui, buvo bandyta didinti irklavimo tempa - nuo iprastinio modelio (Balčiūnas, Skernevičius, 2007) 110-120 y. / min iki 130 y. / min. Sumažèjo raumenų atsipalaidavimo fazè, per kurią kraujas prateka per raumenis, i juos nebuvo pristatomas pakankamas reikiamų medžiagu kiekis ir nepakankamai gerai šalinamos metabolizmo liekanos. Dèl to antrame nuotolio tarpe smarkiai silpo raumenys, mažèjo greitis ir tempas.

Po olimpinių žaidynių grižus i Lietuvą, po 2 savaičiu buvo atlikti išplèstiniai tyrimai VPU Sporto mokslo institute. Sportininku fizinès galios ir funkcinio pajègumo rodikliai vèl buvo puikūs, jokių sveikatos sutrikimų nenustatyta.

\section{IŠVADOS}

1. Išnagrinèjus olimpinio ciklo metinius fizinius krūvius matyti, kad sportininkai per metus pakankamai dienų treniravosi ir atliktas reikiamas pratybų krūvis. Treniruotès veiksmingos ir sukelia reikiamus organizmo pokyčius rengiantis iveikti $500 \mathrm{~m}$ nuotoli.

2. Išanalizavus keturmečio olimpinio ciklo varžybų laikotarpio pagrindinių varžybų mezociklą matyti, kad jis sudarytas gerai ir moksliškai pagrịstas. Mikrociklų struktūra aiški, išskirtos dvejos glikolitinès pratybos mikrociklo metu. Pratybos tikslingos, glaustos ir labai specializuotos baidariu irklavimo $500 \mathrm{~m}$ nuotolio varžybose, tačiau paskutiniu momentu prieš pagrindinius startus padidinus irklavimo tempą nespèta tam prisitaikyti.

3. Per keturmeti olimpinį ciklą fizinio išsivystymo, raumenų masės rodikliai kito mažai, specialiojo $500 \mathrm{~m}$ simuliacinio testo rodikliai vis didejo, specialusis anaerobinis alaktatinis galingumas pamažu didèjo.

4. Darome prielaidą, kad nuvykimo laikas ị olimpines žaidynes likus iki starto 6 dienoms buvo nevykęs. Startai sutapo su fizinio darbingumo sumažèjimo, aklimatizacijos faze. Padidintas irklavimo tempas varžybose nebuvo racionalus.

\section{LITERATŪRA}

Alekrinskis, A., Stasiulis, A., Talačka, E., Pečiūnas, E. (2005). Skirtingo amžiaus ir meistriškumo baidarininku ir kanojininkų aerobinis pajėgumas. Sporto mokslas, 3 (41), 26-29.

Alekrinskis, A., Talačka, E. (2003). Akademinio, baidariu ir kanoju irklavimo technikos mokymas. Kaunas: LKKA.

Balčiūnas, E., Skernevičius, J. (2007). Lietuvos baidarininku rengimas. Vilnius.

Byrnes, W. C., Kearney, J. T. (1997). Aerobic and anaerobic contributions during simulated canoe kayak events. Medicine and Science in Sports and Exercise, 29 (5), 220-225.

Clarkson, P. M., Kroll, W., Melchionda, A. M. (1982). Isokinetic strength, endurance and fiber type composition in elite American paddlers. European Journal of Applied Physiology, 48, 67-76.

Čepulėnas, A. (2001). Slidininku rengimo technologija. Kaunas: LKKA.

Gailiūnienė, A., Milašius, K. (2001). Sporto biochemija. Vilnius: LSIC.

Gonestas, E., Strelčiūnas, R. (2003). Taikomoji statistika. Kaunas: LKKA.

Issurin, V. (2008). Block Periodization. Breakthrough in Sport Training. M. Yassis (Ed.). USA: Ultimate Ahtlete Concepts Michigan.
Karoblis, P., Raslanas, A., Steponavičius, K. (2002). Didelio meistriškumo sportininku rengimas. Vilnius: LSIC.

Milašius, K., Raslanas, A., Skernevičius, J., Rudzinskas, M. (1997). Didelio meistriškumo baidarių ir kanojų irkluotojų organizmo funkcinès būklès kaita. Sporto mokslas, 2 (7), 15-19.

Rudzinskas, M., Skernevičius, J., Švedas, E., Baškienė, V. (2004). Lietuvos baidarininkų rengimo 2000 m. olimpinėms žaidynėms metinio ciklo charakteristika. Sporto mokslas, 1 (35), 37-40.

Skernevičius, J., Balčiūnas, E., Pečiukonienė, M. (2007). Baidarininkų specialuji parengtumą sąlygojantys veiksniai. Sporto mokslas, 1 (47), 48-51.

Skernevičius, J., Balčiūnas, E., Rudzinskas, M., Švedas, E. (2003). Lietuvos pajègiausių baidarininkų fizinio išsivystymo, fizinio parengtumo ir funkcinio pajėgumo tyrimo duomenys bei jų ryšys su specialiu galių rodikliais. Sporto mokslas, 1 (31), 65-69.

Skernevičius, J., Dadelienè, R., Balčiūnas, E., Duonėla, A. (2004). Jaunujų baidarininkų specialiojo parengtumo statistiniai duomenys ir jų lyginamoji analizè su pasaulio čempionų rodikliais. Ugdymas. Kūno kultūra. Sportas, 3 (53), 50-57.

Skernevičius, J., Raslanas, A., Dadelienè, R. (2004). Sporto mokslo tyrimu metodologija. Vilnius: LSIC. 
Stasiulis, A., Alekrinskis, A., Barysas, A., Mockus, P. (1998). Didelio meistriškumo baidarininkų treniruočiu krūvio ir aerobinio pajègumo rodikliu dinamika per vieną sezoną. Sporto mokslas, 5 (14), 27-29.

Верхошанский, Ю. В. (1988). Основы специиальной физической подготвки спортсменов. Москва.

Матвеев, Л. П. (1999). Основы общей теории спорта и система падготовки. Киев: Олимпийсая литература.
Платонов, В. Н. (2004). Система падготовки спортсменов в олимпийском спорте. Киев: Олимпийсая литература.

Шуматов, А. М., Шантарович, В. В. (2008). Метаболическая модель байдарочника международного уровня и оченка механизмов энергообеспечения гребли на байдарке: научные груды НИИ физической культуры и спорта республики Беларусь. Минск. С. 196-201.

\title{
PECULIARITIES OF LITHUANIAN HIGH-PERFORMANCE KAYAK PADDLERS' TRAINING IN THE FOUR-YEAR OLYMPIC CYCLE
}

\author{
Egidijus Balčiūnas \\ Vilnius Pedagogical University, Vilnius, Lithuania
}

\begin{abstract}
The technology of high performance athlete training is a complex educational process, which is investigated by a great number of scientists all over the world (Верхошанский, 1988; Karoblis et al., 2002; Čepulènas, 2003; Платонов, 2004; Issurin, 2008). The kayak paddlers' training has also attracted considerable attention of the researchers in Lithuania (Rudzinskas et al., 2001; Alekrinskis et al., 2003; Skernevičius et al., 2003). The training technology underwent some modifications after the length of competitive distances and velocities in them had changed. Different distances require special fitness from kayak paddlers (Issurin, 2008). The training for $500 \mathrm{~m}$ distance is particularly complicated because a number of biochemical processes occur in the body of a paddler competing in this distance (Gailiūnienė, Milašius, 2001; Balčiūnas, Skernevičius, 2007).

The object of the research was the training of Lithuanian high performance kayak paddlers over a fouryear Olympic cycle and changes in their fitness. The goal of the research was to investigate the theoretical material of high performance kayak paddlers' training in Lithuania and to analyse the four-year Olympic cycle training of Lithuanian high performance kayak paddlers.

The change in physical and functional capacities over the four-year Olympic cycle was investigated of two fittest Lithuanian kayak paddlers, who train for European and World championships and the Olympic games,. The analysis also included training planning documentation and training registers as well as athletes' diaries. Physical and functional capacities were measured in the separate annual cycles at the beginning of the preparatory period, in the phase of special training of the preparatory period, in the period of preparatory competitions, before and after the most important competitions.

The analysis of annual physical loads in the Olympic cycle revealed that the athletes trained a sufficient number of days and the training load met the requirements. The training was efficient to achieve the necessary changes in athletes' body relevant for a 500 m distance; however the time of arrival at the Olympic Games was unfavourable: the athletes had to compete in the period of radical functional changes and a decrease in their physical and functional capacity was identified. The analysis of the mesocycle of the main competitions of the competitive period in the four-year Olympic cycle showed that it was scientifically substantiated by the principles of the sports science: the structure of mesocycles was clear, two glycolytic training sessions were highlighted in a microcycle, the practical trainings were purposive, efficient and specialising in a 500 meter kayak paddling distance. However, an increased paddling speed just before the main starts did not allow the organism of the athletes to properly adapt to this. The indicators of physical development and muscle mass did not undergo any significant changes in the four-year Olympic cycle, whereas the results of a special $500 \mathrm{~m}$ simulation test and the indices of special anaerobic alactic capacity gradually increased. Arrival at the Olympic Games 6 days before the start was disastrous because it coincided with the acclimatisation phase of reduced physical working capacity. An increase in the tempo of paddling was not rational at that point. The $11^{\text {th }}$ place in the Olympic Games did not satisfy the athletes themselves and their training staff.
\end{abstract}

Keywords: physical development, physical fitness, functional capacity, physical loads, annual cycle, mesocycle, microcycle.

Gauta 2009 m. sausio 19 d.

Received on January 19, 2009
Egidijus Balčiūnas

Vilniaus pedagoginis universitetas

(Vilnius Pedagogical University)

Studentu g. 39, LT-08106 Vilnius

Lietuva (Lithuania)

Tel +37068680630

E-mail balciunas@bki.lt 